\title{
PERAN SERTA MASYARAKAT dALAM PENGELOLAAN LINGKUNGAN HIdUP MENURUT UNdANG-UNdANG NOMOR 32 TAHUN 2009 TENTANG PERLINdUNGAN dAN PENGELOLAAN LINGKUNGAN HIdUP
}

\author{
Lalu Sabardi \\ Fakultas Hukum Universitas Mataram \\ e-mail: Isabardi@yahoo.co.id
}

\begin{abstract}
community participation in managing environment to be the basic need for all who live physically in an environment changing continually, in the meaning it quality decline continually. Therefore, the community participation to be absolutely important in creating the healthy environemnet. There is a mistaken view on the community participation in managing environement, namely an assumption that the community give information (public information) in the form reconnaisance even their function merely as public relation to make this activty run smoothly without barrier. Therefore, the community participation not only as a tool to achieve a goal but also to be the goal itself.
\end{abstract}

Key-words: Participation, community, Environment

\section{Abstrak}

Peran serta masyarakat dalam pengelolaan lingkungan hidup menjadi kebutuhan dasar semua orang yang secara fisik berada dalam lingkungan kehidupan yang berubah, dalam arti terus menurunnya kualitas lingkungan. Peran serta masyarakat menjadi sesuatu yang mutlak dalam kerangka menciptakan lingkungan hidup yang sehat. Ada kekeliruan mengenai peranserta masyarakat dalam masalah lingkungan, dengan memandang peran serta masyarakat sematamata sebagai penyampaian informasi (public information), penyuluhan, bahkan sekedar alat public relation agar kegiatan tersebut dapat berjalan tanpa hambatan. Karenanya, peran serta masyarakat tidak saja digunakan sebagai sarana untuk mencapai tujuan, tetapi juga digunakan sebagai tujuan (participation is an end itself).

Kata Kunci: Peran Serta, Masyarakat, Lingkungan hidup

\section{A. Pendahuluan}

Pada era global seperti sekarang masalah lingkungan hidup telah menjadi masalah yang mengancam kehidupan manusia sebagai penghuni planet bumi beserta isinya ini. Masalah lingkungan hidup merupakan kewajiban asasi manusia untuk dikelola sebagaimana mestinya menurut amanah Tuhan yang Maha esa, sehingga setiap manusia baik secara langsung maupun tidak langsung bertanggung jawab terhadap kelangsungan lingkungan hidup.

Sebagai bagian dari sebuah negara maka manusia atau individu merupakan warga negara. Permasalahan lingkungan hidup dan pengelolaannya menuntut peran pemerintah, legislator, penegak hukum, serta masyarakat sebagai warga negara. Di negara Indonesia lingkungan hidup yang baik dan sehat merupakan hak asasi setiap warga negara Indonesia sebagaimana diamanatkan dalam Pasal $28 \mathrm{H}$ Undang-Undang Dasar Negara Republik Indonesia Tahun 1945. Untuk menjalankan apa yang telah diamanatkan dalam Undang-
Undang Dasar Negara Republik Indonesia Tahun 1945 tersebut pemerintah dengan persetujuan Dewan Perwakilan Rakyat telah beberapa kali mengundangkan undang-undang mengenai pengelolaan lingkungan hidup :

1. Undang-undang Nomor 4 Tahun 1982 Tentang Ketentuan-ketentuan Pokok Pengelolaan Lingkungan;

2. Undang-undang Nomor 23 Tahun 1997 Tentang Pengelolaan Lingkungan;

3. Undang-undang Nomor 32 Tahun 2009 Tentang Perlindungan dan Pengelolaan Lingkngan Hidup.

Hal-hal yang melatarbelakangi pembuatan Undang-undang tersebut diantaranya adalah pembangunan ekonomi nasional yang diselenggarakan berdasarkan prinsip pembangunan berkelanjutan dan berwawasan lingkungan. Pada kenyataannya bahwa pemanasan global yang semakin meningkat mengakibatkan perubahan iklim sehingga memperparah penurunan kualitas lingkungan hidup karena itu perlu dilakukan perlindungan 
dan pengelolaan lingkungan hidup, bahwa agar lebih menjamin kepastian hukum dan memberikan perlindungan terhadap hak setiap orang untuk mendapatkan lingkungan hidup yang baik dan sehat sebagai bagian dari perlindungan terhadap keseluruhan ekosistem.

Berdasarkan hal demikian, peran serta masyarakat menjadi sesuatu yang mutlak dalam kerangka menciptakan lingkungan hidup yang sehat. Makna kesehatan tidak semata secara fisik dengan lingkungan yang baik. Lebih dari itu kesehatan fisik sebagai akibat lingkungan yang baik merupakan prasyarat sehatnya jiwa yang tentunya merupakan aset sumber daya manusia yang sangat mendasar dan penting.

Berdasarkan uraian di atas, permasalahan dalam penelitian ini adalah menyangkut: (1) Bagaimanakah makna yuridis peranserta masyarakat dalam pengelolaan lingkungan hidup?; dan (2) Apakah relevansinya peranserta masyarakat dalam perlindungan dan pengelolaan lingkungan hidup?

\section{B. Metode Penelitian}

Penelitian adalah penelitian hukum yang bertolak dari ketentuan aturan perundangundangan yaitu penelitian yang dilakukan terhadap asas-asas hukum yang ada di dalam ketentuan ketentuan tentang lingkungan hidup, secara khusus berkenaan dengan peranserta masyarakat dalam pengelolaan lingkungan hidup. Sehubungan dengan hal tesebut, elaborsinya merupakan tipe penelitian sinkronisasi yang akan mengkaji sinkonisasi yang sifatnya vertikal yaitu antar peraturan perundangan yang atas dan aturan di bawahnya. Juga sinkronisasi secara horizontal yang akan melakukan pengkajian terhadap aturan sejenis pada aturan tentang lingkungan hidup. Bahan-bahan hukum selanjutnya dinalisis secara kualitatif kemudian ditarik kesimpulan secara deduktif.

\section{Hasil Penelitian dan Pembahasan}

\section{Peran masyarakat dalam Perlindungan} dan Pengelolaan Lingkungan Hidup

Ketentuan dalam Pasal $28 \mathrm{H}$ ayat (1) Undang-undang Dasar Negara Republik Indonesia Tahun 1945 telah dicantunkan bahwa,"Setiap orang berhak hidup sejahtera lahir dan batin, bertempat tinggal, dan mendapat lingkungan yang baik dan sehat serta berhak memperoleh pelayanan kesehatan". Atas dasar pengaturan tersebut, maka warga negara untuk lingkungan yang baik dan sehat merupakan salah satu bentuk hak sosial dalam fundamental right. Bentuk perwujudan dijamin hak atas lingkungan yang baik and benar dalam UU No.32 Tahun 2009 tentang Perlindungan dan Pengelolaan Lingkungan Hidup, yang disebut dengan UU PPLH.

Dalam kerangka peran masyarakat dan negara, maka untuk melindungi hak atas lingkungan yang baik dan sehat, telah diterapkan oleh pemerintah berbagai isntrumen ekonomik lingkungan hidup. Instrumen-instrumen hukum lingkungan yang berfungsi sebagai sarana pencegahan pencemaran lingkungah akibat pertambangan meliputi: Baku Mutu Lingkungann (BML), Analisis Mengenai Dampak Lingkungan (AMDAL), Perijinan Lingkungan, Instrumen ekonomik dan Audit Lingkungan. Dalam prakteknya instrumen langsung yang ada tersebut, belum mampu untuk mengendalikan pencemaran secara efektif. Keberadaan instrumen ekonomik, menjadi pelengkap dari instrumen pengaturan langsung yang belum maksimal, untuk menguatkan dalam pengendalian pencemaran lingkungan hidup di bidang lingkungan hidup.

Menurut Abdul Gani, salah satu instrumen yang memadai adalah hukum dengan berbagai macam bentuk perundang-undangan. Dalam hal ini instrumen hukum yang diinginkan adalah hukum yang mampu memiliki ketanggapan sosial, kepekaan terhadap kebijaksanaan (policy) negara yang dijadikan bagi pemenuhan kebutuhan-kebutuhan dasar manusia, tangguh berhadapan dengan setiap upaya penyalagunaan kekuaaan yang lazimnya dilakukan aparat birokrasi, dan siap melindungi hak-hak dan hak manusia rakyat Indoenesia, (Aboel Gani : 1990 : 87).

Keterbukaan pemerintah yang dimaksud adalah keterbukaan dalam prosedur yang meliputi 3 aspek penting yakni:

a. Kewajiban pemerintah untuk memberikan informasi;

b. kemungkinan peran serta masyarakat dalam mengambil keputusan dan

c. pengumaman keputusan pemerintah.

Masyarakat memiliki hak dan kesempatan yang sama dan seluas-luasnya untuk berperan aktif dalam perlindungan dan pengelolaan lingkungan. Masyarakat juga berhak mengajukan gugatan perwakilan kelompok untuk kepentingan dirinya sendiri dan/atau untuk kepentingan masyarakat apabila 
mengalami kerugian akibat pencemaran dan/ atau kerusakan lingkungan hidup (Pasal 91 UU PPLH).

Disisi lain pada Pasal 28 terkait jaminan hak kebebasan berkumpul, UU No.8 Tahun 1985 tentang Organisasi Kemasyarakan dan PP No.8 Tahun 1986 tentang Pelaksana UU No.8 Tahun 1985 tersebut. Pasal 1 UU No. 8 Tahun 1985, yang dimaksud organisasi sosial (orsos) adalah: " ,,, adalah organisasi yag didirikan secara sekarela oleh warga negara $\mathrm{RI}$, atas dasar persamaan daam aktivitas, profesi, fungsi, agama, dan keyakinan dalam pembangunan nasional yang ditujukan untuk mencapai cita-cita nasional dalam kerangka NKRI.

Dalam kaitannya dengan peran serta masyarakat, Instruksi Menteri Dalam Negari Nomor 8 Tahun 1990 tentang Pembinaan LSM, yang dimaksud LSM adalah organisasi atau lembaga yang dibentuk oleh masyarakat, warga negara RI secara sukarela atas kehendak sendiri dan berminat serta bergerak dalam bidang kegiatan tertentu yang ditetapkan oleh organisasi atau lembag sebagai wujud partisipasi atau peran serta masyarakat dalam upaya meningkatkan taraf hidup dan kesejahteran masyarakat yang menitikberatkan kepada pengabdian secara swadaya.

Peran serta mempunyai makna terhadap perlindungan hukum preventif bagi rakyat. Masyarakat dapat mengemukan kepentingankepentingan melalui keberatan, dengar pendapat, serta bentuk-bentuk peran serta lainnya. Untuk itu perlu adanya kewajiban organ pemerintahan untuk memberikan informasi dan hak rakyat untuk didengarkan.

Seperti halnya di negara-negara berkembang lainya, bagi Indonesia masalah pencemaran lingkungan sebagai ganguan terhadap tata kehidupan manusia terutama disebabkan oleh peningkatan jumlah penduduk yang pesat, pemanfaatan sumber daya alam yang berlebihan, pemanfaatan teknologi yang tidak sesuai dengan kondisi alam yang ada dan pola perilaku manusia terhadap alam, dalam hubungan ini peran masyarakat dan pemerintah akan sangat penting sekali dalam penyeimbangan antara pemanfaatan alam dan perbaikan terhadap alam.

Masalah yang sangat berpengaruh adalah perilaku manusia yang tidak lagi menghargai alam dimana manusia adalah bagian dari alam dan kondisi riil di mayarakat dicontohkan dengan penebangan hutan yang tidak disertai dengan penenaman kembali, pembuangan limbah industri dan sampah rumah tangga secara bebas tanpa mempedulikan implikasi dari perbuatan tersebut.

Mencari siapa yang bersalah dan siapa yang mesti bertanggung jawab terhadap kerusakan lingkungan hidup bukanlah cara yang arif dan bijak. Lingkungan hidup merupakan persoalan kolektif yang membutuhkan partisipasi semua komponen bangsa untuk mengurus dan mengelolanya. Pemerintah, tokoh-tokoh masyarakat, Lembaga Swadaya Masyarakat (LSM), semua warga masyarakat, dan komponen bangsa yang lain harus memiliki "kemauan politik" untuk bersama-sama menjaga kelestarian lingkungan hidup dari ulah tangan jahil para preman dan penjahat lingkungan (Rohmijati : $2010: 32$ ).

Hal di atas itu harus dibarengi dengan tindakan hukum yang tegas terhadap pelaku kejahatan lingkungan hidup yang nyata-nyata telah terbukti menyengsarakan banyak umat manusia. Setiap orang adalah bagian dari masyarakat dan masyarakat memiliki hak, kewajiban dan peran yang sama dalam pengelolaan lingkungan, tanpa terkecuali masyarakat desa, pelosok maupun kota, karena ruang lingkup lingkungan bukan hanya ditempat-tempat tertentu saja namun seluruh wilayah Negara Kesatuan Republik Indonesia. Keberadaan masyarakat akan efektif sekali jika peranya dalam mengontrol pengelolaan lingkungan yang ada.

Hak Masyarakat adalah:

a. Setiap orang berhak atas lingkungan hidup yang baik dan sehat sebagai bagian dari hak asasi manusia.

b. Setiap orang berhak mendapatkan pendidikan lingkungan hidup, akses informasi, akses partisipasi, dan akses keadilan dalam memenuhi hak atas lingkungan hidup yang baik dan sehat.

c. Setiap orang berhak mengajukan usul dan/atau keberatan terhadap rencana usaha dan/atau kegiatan yang diperkirakan dapat menimbulkan dampak terhadap lingkungan hidup.

d. Setiap orang berhak untuk berperan dalam perlindungan dan pengelolaan lingkungan hidup sesuai dengan peraturan perundang-undangan. 
e. Setiap orang berhak melakukan pengaduan akibat dugaan pencemaran dan/atau perusakan lingkungan hidup, (Nuryanto : $2011: 43$ ).

Berdasarkan sifatnya, peran serta masyarakat dalam proses pengambilan keputusan berkaitan dengan lingkungan dibedakan menjadi dua yaitu konsultatif dan kemitraan. Pola partisipatif yang bersifat konsultatif ini biasanya dimanfaatkan oleh pengambilan kebijakan sebagai suatu strategi untuk mendapatkan dukungan masyarakat (public support).

Di dalam pendekatan yang bersifat konsultatif ini meskipun anggota masyarakat yang berkepentingan mempunyai hak untuk didengar pendapatnya dan hak untuk diberitahu, tetapi keputusan akhir tetap ada ditangan kelompok pembuat keputusan tersebut (pemrakarsa). Pendapat masyarakat di sini bukanlah merupakan faktor penentu dalam pengambilan keputusan, selain sebagai strategi memperoleh dukungan dan legitimasi publik (Samsul Wahidin : 2012 : ${ }^{8)}$.

Sedangkan pendekatan partisipatif yang bersifat kemitraan lebih menghargai masyarakat lokal dengan memberikan kedudukan atau posisi yang sama dengan kelompok pengambil keputusan. Dengan demikian keputusan bukan lagi menjadi monompoli pihak pemerintah dan pengusaha, tetapi ada bersama dengan masyarakat. Peran masyarakat terhadap perlindungan dan pengelolaan lingkungan hidup mencakup tahap perencanaan, pelaksanaan, dan evaluasi. Hakekat sebenarnya dari hak berperan serta adalah dalam prosedur pengambilan keputusan tentang ijin lingkungan.

Mengenai fungsi peran serta di bidang lingkungan hidup, Koesnadi Hardjasoemantri mengemukakan: "Peran serta masayarakat dalam pengelolaan lingkungan hidup mempunyai jangkauan luas. Peran serta tersebut tidak hanya meliputi peran serta para individu yang terkena berbagai peraturan atau keputusan administratif, akan tetapi meliputi pula peranserta kelompok dan organisasi dalam masyarakat. Peranserta efektif dapat melampaui kemampuan orang seorang, baik dari sudut kemampuan keuangan maupun dari sudut kemampuan pengetahuannya, sehingga peran serta kelompok dan organisasi sangat diperlukan, terutama yang bergerak di bidang lingkungan hidup." (Koesnadi Hardjasumantri : 2003 : 12).
Peran serta masyarakat terasa penting dalam prosedur administratif pengelolaan lingkungan, seperti misalnya perijinan, analisis mengenai dampak lingkungan dan sebagainya. Namun demikian, dewasa ini masih terdapat kekawatiran terhadap asas keterbukaan dan peranserta masyarakat dalam pengelolaan lingkungan hidup.

Di dalam Undang-undang Nomor 32 Tahun 2009 Tentang Perlindungan dan Pengelolaan Lingkungan Hidup Pasal 70 Ayat (1) disebutkan bahwa "Masyarakat memiliki hak dan kesempatan yang sama dan seluas-luasnya untuk berperan aktif dalam perlindungan dan pengelolaan lingkungan hidup". Dalam pasal 70 ayat (2) peran masyarakat dalam perlindungan dan pengelolaan lingkungan hidup dapat berupa:

a. pengawasan sosial;

b. pemberian saran, pendapat, usul, keberatan, pengaduan;

c. penyampaian informasi dan/atau laporan.

Sedangkan pasal 70 ayat (3) disebutkan bahwa peran masyarakat dilakukan untuk:

a. meningkatkan kepedulian dalam perlindungan dan pengelolaan lingkungan hidup;

b. meningkatkan kemandirian, keberdayaan masyarakat, dan kemitraan;

c. menumbuhkembangkan kemampuan dan kepeloporan masyarakat;

d. menumbuhkembangkan ketanggapsegeraan masyarakat untuk melakukan pengawasan sosial;

e. mengembangkan dan menjaga budaya dan kearifan lokal dalam rangka pelestarian fungsi lingkungan hidup.

Tentang Peran masyarakat dalam Perlindungan dan Pengelolaan Lingkungan Hidup Menurut Undang-Undang Nomor 32 Tahun 2009, adalah sebagai contoh beberapa perilaku yang bijak saat di dalam hutan adalah: Rochmijati : 2010 : 54).

a. tidak mencoret-coret batang pohon dan bebatuan yang ada di hutan. Perilaku mencoret-coret pohon dan bebatuan selain merusak keindahan keindahan hutan, juga dapat menyakiti pohon. Kenapa? karena tindakan ini dapat menutupi stomata (tempat keluar masuknya udara, yakni CO2 dan O2) yang secara tidak langsung akan mengganggu pertukaran udara dari sel tumbuhan ke lingkungan dan sebaliknya. 
Hutan mempunyai peran penting dalam mengurangi pencemaran udara.

b. tidak menangkap, melukai, dan membunuh hewan penghuni hutan. Perilaku mengganggu hewan (satwa) yang hidup liar di hutan meskipun binatang tersebut bukan termasuk binatang langka dan dilindungi dapat mengganggu keseimbangan ekosistem.

c. saat berkemah di hutan, mempergunakan tempat yang telah tersedia. Atau jika tidak tersedia tempat berkemah, pergunakanlah bagian hutan yang agak lapang dan datar tanpa perlu menebang pohon, sekalipun hanya semak, perdu ataupun pohon kecil.

d. tidak meninggalkan puntung rokok yang belum benar-benar mati. Meskipun hanya bara kecil tetapi puntung rokok bisa menjadi salah satu penyebab kebakaran hutan, terutama saat musim kemarau.

e. tidak meninggalkan sampah, terutama sampah anorganik seperti plastik dan kaleng.

f. menyimpan sampah yang kita hasilkan dalam suatu wadah khusus kemudian buanglah di tempat sampah yang semestinya atau dimusnahkan di luar hutan atau dimusnahkan. Akan lebih baik lagi jika sampah-sampah yang terdapat di hutan ikut diambil.

g. mempergunakan ranting atau daun yang telah patah atau jatuh saat membuat api unggun. Perilaku menebang pohon untuk membuat api unggun dapat merusak hutan.

h. memadamkan api unggun jika telah selesai hingga benar-benar padam termasuk bara api yang tersisa. Bersihkan tempat bekas api unggun tersebut.

i. tidak membawa pulang tumbuhan atau binatang dari hutan. Simpanlah kenangan manis kamu selama berada di hutan di dalam kamera foto atau kamera video sebagai oleh-oleh.

Sikap dan perilaku bijak di dalam hutan ini terlihat sederhana dan kecil namun memberikan manfaat yang besar bagi kelestarian alam dan hutan. Dengan perilaku bijak seperti ini berarti kita mampu menikmati tanpa menyakiti.

2. Peran masyarakat dalam Perlindungan dan Pengelolaan Lingkungan Hidup Menurut Undang-Undang Nomor 32 Tahun 2009 a. Pengawasan Sosial

Di dalam negara Indonesia yang menganut sistem demokrasi perwakilan maka masyarakat dapat menyampaikan aspiransinya melalui keterwakilannya dalam lembaga parlemen dalam hal ini Dewan Perwakilan Rakyat (DPR) atau Dewan Perwakilan Rakyat Daerah (DPRD). Parlemen atau lembaga perwakilan rakyat mempunyai 3 fungsi pokok yaitu: (Jimly Asshiddiqqie : 2006 : 43)

1) Fungsi representasi (perwakilan)

2) Fungsi pengawasan (control)

3) Fungsi pengaturan atau legislasi menyangkut 4 bentuk kegiatan yaitu prakarsa pembuatan undangundang, pembahasan rancangan undang-undang, persetujuan atas pengikatan atau ratifikasi atas perjanjian atau persetujuan internasional dan dokumendokumen hukum yang mengikat lainnya (Jimly Asshiddiqqie : $2006: 43$ ).

Peran masyarakat dalam hal ini adalah lebih kepada fungsi pengaturan atau legislasi karena keterwakilannya di dalam lembaga perwakilan akan menentukan perundang-undangan atau peraturan-peraturan yang akan dibuat. Ikut melakukan pengawasan terhadap pembuatan undang-undang/ peraturan, rancangan undang-undang/ peraturan mengenai lingkungan hidup yang memperhatikan kelangsungan lingkungan hidup.

b. Pemberian Saran, Pendapat, Usul, Keberatan, Pengaduan

Peran masyarakat dapat berupa pemberian saran dan pendapat terhadap langkah perlindungan dan pengelolaan lingkungan hidup yang telah dilakukan oleh pemerintah atau lembaga/ organisasi lingkungan hidup. Keberatan terhadap tindakan-tindakan yang dapat merusak atau mengganggu proses perlindungan dan pengelolaan lingkungan hidup. Menyampaikan pengaduan kepada lembaga penegak hukum/ instansi yang berwenang apabila menemukan tindakan yang merusak lingkungan hidup.

Apabila dikemudian hari menimbulkan sengketa diantara masyarakat yang keberatan/melakukan pengaduan maka penyelesaian sengketa lingkungan hidup dapat ditempuh melalui pengadilan atau 
di luar pengadilan. Pilihan penyelesaian sengketa lingkungan hidup dilakukan secara suka rela oleh para pihak yang bersengketa (Jimly Asshiddiqqie: $2006: 43$ ).

c. Penyampaian Informasi dan/atau laporan Masyarakat dapat segera menyampaikan informasi dan/ laporan berkaitan dengan keadaan suatu lingkungan hidup kepada pemerintah atau organisasi lingkungan hidup sehingga apabila terdapat permasalahan segera dapat diupayakan perbaikan dan pencegahan kerusakan lingkungan hidup yang lebih parah. (Rochmijati : 2010 : 54).

Tentang perlunya Peran Masyarakat dalam Perlindungan dan Pengelolaan Lingkungan Hidup menurut UndangUndang Nomor 32 Tahun 2009, bahwa meningkatkan kepedulian dalam perlindungan dan pengelolaan lingkungan hidup. Hampir tiap hari di televisi, surat kabar, koran, dan media informasi lainnya kita mendengar berbagai bencana di setiap daerah seperti banjir, gunung meletus, gempa bumi, lumpur lapindo, pencemaran air dll. Bencana-bencana dan masalahmasalah lingkungan hidup tersebut akan membuat kita berpikir dan menyadari pentingnya melakukan perlindungan dan pengelolaan lingkungan hidup.

Berangkat dari masing-masing individu untuk melakukan tindakan perlindungan dan pengelolaan lingkungan hidup maka akan dalam satu kelompok akan membawa dampak yang sangat besar bagi perbaikan lingkungan hidup tersebut. Pada umumnya masyarakat pasti memiliki budaya dan adat istiadat lokal yang lebih mengedepankan keharmonisan dengan alam. Mereka pantang melakukan perusakan terhadap alam karena dinilai bisa menjadi ancaman besar bagi budaya mereka. Alam bukan hanya sumber kehidupan, melainkan juga sahabat dan guru yang telah mengajarkan banyak hal bagi mereka.

Dari alam mereka menemukan falsafah hidup, membangun religiositas dan pola hidup seperti yang mereka anut hingga kini. Memanfaatkan alam tanpa mempertimbangkan eksistensi budaya setempat tidak beda dengan penjajahan. Kendala yang muncul dari masyarakat Indonesia dalam kaitannya dengan lingkungan hidup adalah :
1) budaya masyarakat, yaitu adanya karakter budaya masyarakat Indonesia terutama di Jawa yang cenderung penghindaran konflik dan kesepakatan (Bruce Mitchell, B setiawan, Dwita Hadi Rahmi : 2010

: 429), dimana ekspresi langsung ketidaksetujuan, terutama dengan gagasan atau rencana pihak yang lebih tinggi tidak pernah terjadi. Keterusterangan menolak atau melawan, mengkritik langsung, secara sosial tidak umum dan tidak dibenarkan.

2) moral masyarakat, yaitu sebagian masyarakat menganggap bahwa sumber daya alam diciptakan Tuhan yang Maha esa untuk manusia sehingga manusia berhak untuk mengeksploitasinya. Anggapan salah dari sebagian orang bahwa hari ini untuk dinikmati hari kemudian biar dipikirkan nanti saja.

3) pendidikan masyarakat, yaitu tingkat pendidikan masyarakat Indonesia yang masih rendah mengakibatkan pengertian dan pemahaman pentingnya lingkungan hidup ikut rendah.

4) ekonomi masyarakat, yaitu Indonesia termasuk negara berkembang di mana masyarakatnya masih berpenghasilan rendah. Dengan keterbatasan ekonomi tersebut, maka masyarakat mengeksploitasi sebesar-besarnya lingkungan yang ada di sekitarnya untuk memenuhi kebutuhannya.

5) Teknologi, yaitu masih terbatasnya teknologi yang memadai yang dapat digunakan oleh masyarakat untuk pengelolaan lingkungan hidup dan biasanya memerlukan biaya yang mahal.

3. Makna Peran serta Masyarakat dalam Perlindungan dan Pengelolaan Lingkungan Hidup

a. Peran serta masyarakat

Pengelolaan lingkungan termasuk pencegahan, penanggulangan kerusakan dan pencemaran serta pemulihan kualitas lingkungan telah menuntut dikembangkannya berbagai perangkat 
kebijakan dan program serta kegiatan yang didukung oleh sistem pendukung pengelolaan lingkungan lainnya.

Sistem tersebut mencakup kemantapan kelembagaan, sumberdaya manusia dan kemitraan lingkungan, disamping perangkat hukum dan perundangan, tersedianya informasi serta pendanaan. Sifat keterkaitan (interdependensi) dan keseluruhan (holistik) dari esensi lingkungan telah membawa konsekuensi bahwa pengelolaan lingkungan, termasuk sistem pendukungnya tidak dapat berdiri sendiri, akan tetapi terintegrasikan dan menjadi roh dan bersenyawa dengan seluruh pelaksanaan pembangunan sektor dan daerah.

Peran serta masyarakat, pada dasarnya adalah suatu proses yang melibatkan masyarakat umumnya dikenal sebagai peran serta masyarakat, yaitu proses komunikasi dua arah yang berlangsung terus-menerus untuk meningkatkan pengertian masyarakat secara penuh atas suatu proses kegiatan, dimana masalah-masalah dan kebutuhan lingkungan sedang dianalisa. (Waluyo : 2002 : 33).

Begitu luasnya pengertian dan pemahaman peran serta masyarakat dalam pengelolaan lingkungan, sehingga menimbulkan beraneka ragam penafsiran, yang sering kali penafsiran pihak yang kuatlah yang timbul dan mereduksi peran serta yang bermakna (meaningfull participation). Dari sudut terminologi peran serta masyarakat dapat diartikan sebagai suatu cara melakukan interaksi antara dua kelompok; Kelompok yang selama ini tidak diikutsertakan dalam proses pengambilan keputusan (non-elite) dan kelompok yang selama ini melakukan pengambilan keputusan (elite).

Banyak yang memandang peran serta masyarakat sematamata sebagai penyampaian informasi (public information), penyuluhan, bahkan sekedar alat public relation agar kegiatan tersebut dapat berjalan tanpa hambatan. Karenanya, peran serta masyarakat tidak saja digunakan sebagai sarana untuk mencapai tujuan, tetapi juga digunakan sebagai tujuan (participation is an end itself) (Leden Marpaung : 1997 : 12).
Dalam peran serta masyarakat dengan pola hubungan konsultatif antara pihak pengambil keputusan dengan kelompok masyarakat yang berkepentingan beserta anggota masyarakat lainnya yang mempunyai hak untuk didengar pendapatnya dan untuk diberi tahu, dimana keputusan terakhir tetap berada di tangan pembuat keputusan tersebut. Sedang dalam konteks peran serta masyarakat yang bersifat kemitraan, pembuat keputusan dan anggota masyarakat merupakan mitra yang relatif sejajar kedudukannya. Mereka bersama-sama membahas masalah, mencari alternatif pemecahan masalah dan membahas keputusan.

Selain hal di atas, penyertaan masyarakat akan juga memberikan informasi yang berharga kepada para pengambil keputusan, peran serta masyarakat juga akan mereduksi kemungkinan penolakan masyarakat untuk menerima keputusan. Pemberian akses atas informasi tentang pengelolaan lingkungan juga merupakan bagian yang tidak terpisahkan dari aspek peran serta masyarakat dalam pengelolaan lingkungan hidup.

Waluyo, dengan mengutip Canter (1977), Cormick (1979), Goulet (1989) dan Wingert (1979) merinci peran serta masyarakat sebagai berukut: (Waluyo : 2002 : 35)

b. Peran Serta Masyarakat sebagai suatu Kebijakan

Penganut paham ini berpendapat bahwa peran serta masyarakat merupakan suatu kebijaksanaan yang tepat dan baik untuk dilaksanakan. Paham ini dilandasi oleh suatu pemahaman bahwa masyarakat yang potensial dikorbankan atau terkorbankan oleh suatu proyek pembangunan memiliki hak untuk dikonsultasikan (right to be consulted).

c. Peran Serta Masyarakat sebagai Strategi

Penganut paham ini mendalilkan bahwa peran serta masyarakat merupakan strategi untuk mendapatkan dukungan masyarakt (ppublic support). Pendapat ini didasarkan kepada suatu paham bahwa bila masyarakat merasa memiliki akses terhadap pengambilan keputusan dan kepedulian masyarakat 
kepada pada tiap tingkatan pengambilan keputusan didokumentasikan dengan baik, maka keputusan tersebut akan memiliki kredibilitas.

d. Peran Serta Masyarakat sebagai Alat Komunikasi

Peran serta masyarakat didayagunakan sebagai alat untuk mendapatkan masukan berupa informasi dalam proses pengambilan keputusan. Persepsi ini dilandasi oleh suatu pemikiran bahwa pemerintah dirancang untuk melayani masyarakat, sehingga pandangan dan preferensi dari masyarakat tersebut adalah masukan yang bernilai guna mewujudkan keputusan yang responsif.

e. Peran Serta Masyarakat sebagai Alat Penyelesaian Sengketa

Dalam konteks ini peran serta masyarakat didayagunakan sebagai suatu cara untuk mengurangi atau meredakan konflik melalui usaha pencapaian konsensus dari pendapatpendapat yang ada. Asumsi yang melandasi persepsi ini adalah bertukar pikiran dan pandangan dapat menigkatkan pengertian dan toleransi serta mengurangi rasa ketidakpercayaan (misstrust) dan kerancuan (biasess).

f. Peran Sera Masyarakat sebagai Terapi

Menurut persepsi ini, peran serta masyarakat dilakukan sebagai upaya untuk "mengobati" masalah-masalah psikologis masyarakat seperti halnya perasaan ketidak berdayaan (sense of powerlessness), tidak percaya diri dan perasaan bahwa diri mereka bukan komponen penting dalam masyarakat.

g. Peranserta Masyarakat dan Penegakan Hukum Lingkungan

Penegakan hukum pidana dalam Undang-Undang 32 Tahun 2009 ini memperkenalkan ancaman hukuman minimum di samping maksimum, perluasan alat bukti, pemidanaan bagi pelanggaran baku mutu, keterpaduan penegakan hukum pidana, dan pengaturan tindak pidana korporasi. Penegakan hukum pidana lingkungan tetap memperhatikan azas ultimum remedium yang mewajibkan penerapan penegakan hukum pidana sebagai upaya terakhir setelah penerapan penegakan hukum administrasi dianggap tidak berhasil (Leden Marpaung : 1997 : 56).
Penerapan asas ultimum remedium ini hanya berlaku bagi tindak pidana formil tertentu, yaitu penindakan terhadap pelanggaran baku mutu air limbah, emisi, dan gangguan. Dalam pelaksanaan penegakkan hukum yang terdapat dalam Undang-Undang ini meliputi prinsipprinsip perlindungan dan pengelolaan lingkungan hidup yang didasarkan pada tata kelola pemerintahan yang baik karena dalam setiap proses perumusan dan penerapan instrumen pencegahan pencemaran dan/atau kerusakan lingkungan hidup serta penanggulangan dan penegakan hukum mewajibkan pengintegrasian aspek transparansi, partisipasi, akuntabilitas, dan keadilan.

Melalui Peraturan Perundangan ini juga, Pemerintah memberi kewenangan yang sangat luas kepada pemerintah daerah dalam melakukan perlindungan dan pengelolaan lingkungan hidup di daerah masing-masing yang tidak diatur dalam Undang-Undang Nomor 23 Tahun 1997 tentang Pengelolaan Lingkungan Hidup. pengambil keputusan, peran serta masyarakat juga akan mereduksi kemungkinan penolakan masyarakat untuk menerima keputusan. Pemberian akses atas informasi tentang pengelolaan lingkungan juga merupakan bagian yang tidak terpisahkan dari aspek peran serta masyarakat dalam pengelolaan lingkungan hidup (R.M. Gatot Soemartono. P. : 1996 : 17).

Adapun tujuan dari peran serta masyarakat sejak tahap perencanaan adalah untuk menghasilkan masukan dan persepsi yang berguna dari warga negara dan masyarakat yang berkepentingan (public interest) dalam rangka meningkatkan kualitas pengambilan keputusan lingkungan.

Proses peran serta masyarakat haruslah terbuka untuk umum, peran serta masyarakat akan mempengaruhi kredibilitas (accountability) badan yang bersangkutan. Dengan cara mendokumentasikan perbuatan keputusan badan negara ini, sehingga mampu menyediakan sarana yang memuaskan jika masyarakat dan bahkan pengadilan merasa perlu melakukan pemeriksaan atas pertimbangan yang telah diambil ketika membuat keputusan tersebut. yang pada akhirnya akan dapat 
memaksa adanya tanggung jawab dari badan negara tersebut atas kegiatan yang dilakukannya.

Perlunya peran serta msyarakat telah pula diungkapkan oleh Prof. Koesnadi Hardjasoemantri, bahwa selain itu memberikan informasi yang berharga kepada para pengambil keputusan, peran serta masyarakat akan mereduksi kemungkinan kesediaan masyarakat untuk menerima keputusan.

Selanjutnya, peran serta masyarakat akan membantu perlindungan hukum. Bila suatu keputusan akhir diambil dengan memperhatikan keberatankeberatan yang diajukan, maka akan memperkecil kemungkinan pengajuan perkara ke pengadilan. Karena masih ada alternatif pemecahan yang dapat diambil sebelum sampai pada keputusan akhir (Koesnadi Hardjasumantri : 2003 : 67).

Terhadap hal di atas, Hardjasoemantri melihat perlu dipenuhinya syarat-syarat berikut agar peran serta masyarakat menjadi efektif dan berdaya guna

1) Pemastian penerimaan informasi dengan mewajibkan pemrakarsa kegiatan mengumumkan rencana kegiatannya.

2) Informasi Lintas-batas (transfortier information); mengingat masalah lingkungan tidak mengenal batas wilayah yang dibuat manusia, maka ada kemungkinan kerusakan lingkungan di satu daerah akan pula mempengaruhi propinsi atau negara tetangga. Dengan demikian pertukaran informasi dan pengawasan yang melibatkan daerah-daerah terkait menjadi penting;

3) Informasi tepat waktu (timely information); suatu proses peran serta masyarakat yang efektif memerlukan informasi yang sedini dan seteliti mungkin, sebelum keputusan terakhir diambil. Sehingga, masih ada kesempatan untuk memeprtimbangkan dan mengusulkan altenatif-alternatif pilihan;

4) Informasi yang lengkap dan menyeluruh (comprehensive information); walau isi dari suatu informasi akan berbeda tergantumg keperluan bentuk kegiatan yang direncanakan, tetapi pada intinya informasi itu haruslah menjabarkan rencana kegitana secara rinci termasuk alternatif-alternatif lain yang dapat diambil;

5) Informasi yang dapat dipahami (comprehensive information); seringkali pengambilan keputusan di bidang lingkungan meliputi masalah yang rumit, kompleks dan bersifat teknis ilmiah, sehingga haruslah diusahakan informasi tersebut mudah dipahami oleh masyarakat awam. Metode yang sering digunakan adalah kewajiban untuk membuat uraian singkat atas kegiatan yang dilakukan (Koesnadi Hardjasumantri : 2003 : 67).

Syarat lain yang dapat ditambahkan selain yang telah diuraikan di atas, adalah keharusan adanya kepastian dan upaya terus-menerus untuk memasok informasi agar penerima informasi dapat menghasilkan informasi yang berguna bagi pemberi informasi.

Peranserta masyarakat sangat bermanfaat bagi tujuan berikut:

1) Menuju masyarakat yang lebih bertanggung jawab;

Kesempatan untuk berperan serta dalam kegiatan publik, akan memaksa orang yang bersangkutan untuk membuka cakrawala pikirannya dan mempertimbangkan kepentingan publik (Mill 1990). Sehingga orang tersebut tidak semata-mata memikirkan kepentingannya sendiri, tetapi akan lebih memiliki sifat bertanggung jawab dengan mempertimbangkan kepentingan bersama.

2) Meningkatkan proses belajar

Pengalaman berperan serta secara psikologis akan memberikan seseorang kepercayaan yang lebih baik untuk berperan serta lebih jauh (Sunarso, Siswanto : 2005 : 34).

3) Mengeliminasi perasaan terasing

Dengan turut aktifnya berperan serta dalam suatu kegiatan, seseorang tidak akan merasa terasing. Karena dengan berperan serta akan meningkatkan perasaan dalam seseorang bahwa ia merupakan bagian dari masyarakat. 
4) Menimbulkan dukungan terhadap

rencana pemerintah

Ketika seseorang langsung terlibat dalam proses pengambilan keputusan yang akan mempengaruhi kehidupannya, mereka cenderung akan mempunyai kepercayaan dan menerima hasil akhir dari keputusan itu. Jadi, program peran serta masyarakat menambah legitimasi dan kredibilitas dari proses perencanaan kebijakan publik. Serta menambah kepercayaan publik atas proses politik yang dijalankan para pengambil keputusan.

5) Menciptakan kesadaran politik John Stuart Mill (1963) berpendapat bahwa peran serta pada tingkat lokal, dimana pendidikan nyata dari peran serta terjadi, seseorang akan "belajar demokrasi". la mencatat bahwa orang tidaklah belajar membaca atau menulis dengan kata-kata semata, tetapi dengan melakukannya. Jadi, hanya dengan terus berpraktek pemerintahan dalam skala kecil akan membuat masyarakat belajar bagaimana mempraktekkannya dalam lingkup yang lebih besar lagi.

6) Sebagai cerminan kebutuhan dan keinginan masyarakat;

Menurut Verba dan Nie (1972) bahw amelalui peran serta masyarakat distribusi yang lebih adil atas keuntungan pembangunan akan didapat, karena rentang kepentingan yang luas tercakup dalam proses pengambilan keputusan.

7) Menjadi sumber dari informasi yang berguna;

Masyarakat sekitar, dalam keadaan tertentu akan menjadi "pakar" yang baik karena belajar dari pengalaman atau karena pengetahuan yang didapatnya dari kegiatan sehari-hari. Keunikan dari peran serta adalah masyarakat dapat mewakili pengetahuan lokal yang berharga yang belum tentu dimiliki oleh pakar lainnya, sehingga pengetahuan itu haruslah termuat dalam proses pembuatan keputusan.
8) Merupakan komitmen sistem demokrasi;

Program peran serta msyarakat membuka kemungkinan meningkatnya akses masyarakat ke dalam proses pembuatan keputusan.

Pada perspektif peran serta masyarakat dalam peraturan perundangundangan lingkungan di Indonesia, maka menurut Satjipto Rahardjo melihat pemerintah merupakan agen utam dalam segenap kegiatan masyarakat, termasuk pembangunan dan pengelolaan lingkungan hidup. Ini berarti pemerintahlah yang bertanggung jawab terhadap perencanaan dan pelaksanaan kegiatan-kegiatan itu (Satjipto Rahardjo : $1989: 67)$.

Di dalam konteks ini, sinyalemen peran serta yang masih rendah menjadi nyata, ketika pada akhirnya peran serta masyarakat hanyalah merupakan proses tarik-menarik antara pemerintah dan pihak masyarakat. Dalam hal ini masyarakat hanyalah mampu untuk mencari ruang gerak peran serta masyarakat yang telah 'diciptakan' pemerintah.

Sejalan dengan hal di atas, sangat relevan untuk kiranya terus digali ruang gerak peran serta masyarakat dalam peraturan perundang-undangan lingkungan yang ada di Indonesia. Tidak hanya khusus dalam UU tersbut, tetapi juga dalam peraturan pelaksanaan sebagai penjabarannya.

4. Relevansinya Peranserta Masyarakat dalam Perlindungan dan Pengelolaan Lingkungan Hidup

Dalam lingkungan hidup yang baik, terjalin suatu interaksi yang harmonis dan seimbang antar komponen-komponen lingkungan hidup. Stabilitas keseimbangan dan keserasian interaksi antar komponen lingkungan hidup tersebut tergantung pada usaha manusia. Karena manusia adalah komponen lingkungan hidup yang paling dominan dalam mempengaruhi lingkungan. Sebaliknya lingkungan pun mempengaruhi manusia. Sehingga terdapat hubungan yang saling mempengaruhi antara manusia dan lingkungan hidupnya. Hal demikian, merupakan interaksi antara manusia dan lingkungan. 
emil Salim mengemukakan bahwa, jaringan hubungan timbal balik antara manusia dengan segala jenis benda, zat organis dan bukan organis serta kondisi yang ada dalam suatu lingkungan membentuk suatu ekosistem. Jaringan hubungan dalam ekosistem ini bisa tumbuh secara stabil apabila berbagai unsur dan zat dalam lingkungan ini berada dalam keseimbangan (Satjipto Rahardjo : 1989 : 76).

Hubungan yang sedemikian erat dan ketergantungan manusia terhadap lingkungannya, seyogyanya menimbulkan kesadaran akan pentingngnya keberlanjutan lingkungan hidup yang lestari dan seimbang sehingga hal tersebut perlu di atur dengan jelas, apalagi sebahagian besar negara di dunia ini menganut sistem atau mengklaim negaranya sebagai negara hukum.

Pemikiran atau konsepsi manusia tentang Negara hukum juga lahir dan berkembang dalam situasi kesejarahan. Karena itu, meskipun konsep negara hukum dianggap sebagi konsep universal, pada daratan implementasi ternyata memiliki karakteristik yang beragam.

Hal di atas dikarenakan adanya pengaruhpengaruh kesejarahan tadi, disamping pengaruh falsafah bangsa, ideologi negara dan lain-lain. Atas dasar itu, secara historis dan praktis, konsep negara hukum muncul dalam berbagai model seperti negara hukum menurut Alquran dan Sunnah atau nomokrasi Islam.

Demikian pula dalam konsep negara hukum menurut eropa Kontinental yang di namakan rechtsstaat, negara hukum menurut konsep Anglo Saxon (rule of law), konsepsocialist legality, dan konsep negara hukum pancasila (Ridwan HR : 2006 : 33).

Sebagai negara hukum, maka usaha penegakan hukum harus berdasar pada prinsip bahwa hukum harus tetap dipegang teguh, karena tegaknya hukum dalam suatu negara hukum merupakan jaminan pengakuan akan hak-hak masyarakat.

Keluarnya Undang-Undang No. 32 Tahun 2009 Tentang Perlindungan dan Pengelolaan Lingkungan Hidup (UUPPLH) dianggap belum bisa menyelesaikan persoalanpersoalan lingkungan banyak mendapat apresiasi dan sebagai upaya yang serius dari pemerintah dalam menangani masalahmasalah pengelolaan lingkungan (Samsul Wahidin : 2012 : 16).

Masih banyak hal-hal yang perlu dibenahi dalam UUPPLH tersebut, seperti dalam Pasal 26 ayat (2) bahwa" pelibatan masyarakat harus dilakukan berdasarkan prinsip pemberian informasi yang transparan dan lengkap serta diberitahukan sebelum kegiatan dilaksanakan".

Dalam pasal ini, tidak diikuti penjelasan seperti apa dan bagaimana bentuk informasi secara lengkap tersebut dan upaya hukum apa yang dapat dilakukan bila hal tersebut tidak dilakukan, begitupula dalam ayat (4) "masyarakat sebagaimana dimaksud pada ayat (1) dapat mengajukan keberatan terhadap dokumen amdal" juga tidak di ikuti penjelasan sehingga dapat menimbulkan kerancuan dalam hal yang seperti apa masyarakat menolak dokumen tersebut, sehingga justru mereduksi hak-hak masyarakat dalam proses awal pembangunan.

Sebanyak 13 (tigabelas) instrumen pencegahan pencemaran dan/atau kerusakan lingkungan hidup yang termuat dalam pasal 14 UU no. 32 Tahun 2009 menjadi dasar peran serta masyarakat.

Dalam UU itu sejatinya ada instrumen baru yang tidak terdapat dalam UUPLH sebelumnya, yaitu Kajian Lingkungan Hidup Strategis (KLHS) yang wajib dilakukan oleh pemerintah dan pemerintah daerah untuk memastikan terintegrasinya prinsip pembangunan berkelanjutan dalam pembangunan suatu wilayah dan/atau kebijakan, rencana dan/atau program (Pasal 15 ayat 1 UU no. 32 tahun 2009).

Pasal 66 dari UUPPLH menyebut tentang peranserta yang sangat penting itu. Dinyatakan bahwa:Setiap orang yang memperjuangkan hak atas linkungan hidup yang baik dan sehat tidak dapat dituntut secara pidana maupun digugat secara perdata".

Tentunya bila ditelaah dengan baik, tidak ada yang salah dari pasal ini. Namun dalam penjelasan pasal ini berbunyi bahwa ketentuan ini dimaksudkan untuk melindungi korban dan / atau pelapor yang menempuh cara hukum akibat pencemaran dan/ atau perusakan lingkungan hidup dan perlindungan dimaksudkan untuk mencegah tindakan pembalasan dari terlapor melalui pemidanaan dan/gugatan perdata dengan tetap memperhatikan kemandirian peradilan.

Kalimat terakhir yang sekaligus penutup dari penjelasan tersebut "dengan tetap memperhatikan kemandirian peradilan merupakan kalimat kunci yang dimaksudkan untuk mematahkan/ mementahkan janji 
dari pasal 66. Artinya diberlakukannya hak perlindungan sebagaimana yang diatur dalam pasal 66 masih harus ditentukan dan diuji lagi oleh peradilan. Bahwa disidang peradilan segala sesuatu (apapun) masih mungkin terjadi termasuk mengabaikan pemberlakuan pasal 66 karena hakim bebas dan memiliki hak mutlak untuk menentukan/menjatuhkan putusannya.

Berdasarkan hal di atas, proses pelibatan masyarakat dalam setiap kegiatan pembangunan khususnya lingkungan hidup dimaksudkan agar dapat:

1) Memberikan informasi dan menampung aspirasi masyarakat (bisa diwakili golongan tertentu) yang diperkirakan terkena dampak rencana kegiatan.

2) Memastikan adanya transparansi dalam keseluruhan proses AMDAL dan rencana usaha dan/atau kegiatan.

3) Menciptakan suasana kemitraan yang setara antara semua pihak yang berkepentingan, yaitu dengan menghormati hak-hak semua pihak untuk mendapatkan informasi dan kewajiban semua pihak untuk menyampaikan informasi yang harus diketahui pihak lain yang terpengaruh.

Peningkatan partisipasi dari masyarakat untuk turut serta menjaga dan memelihara lingkungan, dapatdilakukan dengan berbagai upaya konkret, baik perorangan maupun berkelompok yang secara fungsional tergabung dalam organisasi lingkungan. Organisasi dimaksud baik yang sudah ada maupun adanya keharusan untuk dibentuk sebagai bagian tak terpisahkan dari peran serta masyarakat atas lingkungan hidup yang baik dan sehat.

\section{d. Simpulan}

Bahwasanya masalah lingkungan hidup merupakan kewajiban asasi manusia untuk dikelola sebagaimana mestinya menurut amanah Tuhan yang Maha esa, sehingga setiap manusia baik secara langsung maupun tidak langsung bertanggung jawab terhadap kelangsungan lingkungan hidup. Oleh karena itu peranserta masyarakat dalam menciptakan lingkungn hidup juga berkait erat dengan kewajiban untuk menjaga lingkungan itu sendiri.

Dalam hal ini, peran serta masyarakat menjadi sesuatu yang mutlak dalam kerangka menciptakan lingkungan hidup yang sehat. Makna kesehatan tidak semata secara fisik dengan lingkungan yang baik. Lebih dari itu kesehatan fisik semata.

Pada dasarnya setiap orang adalah bagian dari masyarakat dan masyarakat memiliki hak, kewajiban dan peran yang sama dalam pengelolaan lingkungan, tanpa terkecuali masyarakat desa, pelosok maupun kota, karena ruang lingkup lingkungan bukan hanya ditempat-tempat tertentu saja namun seluruh wilayah Negara Kesatuan Republik Indonesia. Keberadaan masyarakat akan efektif sekali jika perannya dalam mengontrol pengelolaan lingkungan yang ada bisa diwujudkan.

Di dalam rangka pelaksanaan tanggung jawab perlindungan dan pengelolaan lingkungan hidup, organisasi lingkungan hidup berhak mengajukan gugatan untuk kepentingan pelestarian fungsi lingkungan hidup. Hak mengajukan gugatan terbatas pada tuntutan untuk melakukan tindakan tertentu tanpa adanya tuntutan ganti rugi, kecuali biaya atau pengeluaran riil.

Secara alamiah masyarakat pasti memiliki budaya dan adat istiadat lokal yang lebih mengedepankan keharmonisan dengan alam. Mereka pantang melakukan perusakan terhadap alam karena dinilai bisa menjadi ancaman besar bagi budaya mereka. Alam bukan hanya sumber kehidupan, melainkan juga sahabat dan guru yang telah mengajarkan banyak hal bagi mereka. Namun teknologi dan sifat hedonisme menjadikan eksploitasi alam tak terkendali.

Selama ini, terjadi kekeliruan mengenai peranserta masyarakat dalam masalah lingkungan, dengan memandang peran serta masyarakat sematamata sebagai penyampaian informasi (public information), penyuluhan, bahkan sekedar alat public relation agar kegiatan tersebut dapat berjalan tanpa hambatan. Karenanya, peran serta masyarakat tidak saja digunakan sebagai sarana untuk mencapai tujuan, tetapi juga digunakan sebagai tujuan (participation is an end itself).

Bahwasanya tujuan dari peran serta masyarakat sejak tahap perencanaan sampai evaluasi dalam pengelolaan lingkungan adalah untuk menghasilkan masukan dan persepsi yang berguna dari warga negara dan masyarakat yang berkepentingan (public interest) dalam rangka meningkatkan kualitas pengambilan keputusan lingkungan. Karena dengan melibatkan masyarakat yang potensial terkena dampak kegiatan dan kelompok kepentingan (interest groups), para pengambil keputusan dapat menangkap pandangan, kebutuhan dan pengharapan dari masyarakat dan kelompok tersebut dan menuangkannya ke dalam konsep. 


\section{daftar Pustaka}

Anonim. tt. Kitab Undang-Undang Hukum Perdata (KUHPerdata)

Anonim. 1960. Undang-Undang No 5 Tahun 1960 Tentang UUPA

Anonim. 1999. Undang-Undang No 18 Tahun 1999 Tentang Jasa Kontruksi

Anonim. 2004. Undang-Undang No 1 Tahun 2004Tentang Perbendaharaan Negara

Anonim. 2003. Undang-Undang No 17 Tahun 2003 Tentang Keuangan Negara

Anonim. 2005. Peraturan Pemerintah No 6 Tahun 2006 tentang Pengelolaan Barang Milik Negara dan Daerah

Chidir Ali. 1979. Yurisprudensi Indonesia Tentang hukum Agraria; Jual Beli, wewenang keagrarian Pendaftaran Tanah. Jilid 3. Bandung : Bina Cipta.

Delmon, Jeffry. BOO/BOT Projects. 2000. A c ommercial and contractual guide. London: Sweet and Maxweel.

Gautama. 1994. contoh-contoh Kontrak Rekes dan Surat-Surat Resmi Sehari-hari, Jilid I. Bandung: Citra Aditya Bakti.

Harahap, M. yahya. 1998. Ruang Lingkup Permasalahan Ekskusi Bidang Perdata. Jakarta : Gramedia

Indroharto. 2003. Usaha Memahami Undang-Undang Tentang Peradilan Tta Usaha Negara,Buku I Beberapa Pengertian Dsar hukum Tata Negara. Jakarta: Pustaka Sinar Harapan.

J. Satrio.1999. hukum Jaminan, hak-hak Jaminan Kebendaan. Bandung : Citra Aditya Bakti

Mariam Darus Badrulzaman dkk. 2001. Kompilasi hukum Perikatan. Bandung : Citra Aditya Bakti.

—_ Perjanjian dengan Pemerintah ( government contract) Dalam hukum Kontrak di Indonesia

Nazarkhan yasin. 2006. Mengenal Kontrak Kontruksi Di Indonesia, Buku Pertama Seri Hukum Kontruksi, Jakarta : Gramedia Pustaka Utama.

Peter Mahmud Marzuki. 2003. "Batas-Batas Kebebasan Berkontrak," Yuridika, Vol 18 No 3 Mei 2003 2005. Penelitian hukum. Jakarta : Prenada Media.

Philipus M Hadjon. 1987. Perlindungan hukum Bagi Rakyat di Indonesia (Sebuah Study Tentang PrinsipPrinsipnya , Penangananya oleh Pengadilan Dalam Lingkungan Peradilan Umum dan Pembentukan Administrasi Negara. Surabaya : PT Bina Ilmu.

Simamora, yohannes Sogar. 2006. "Prinsip Hukum Kontrak Dalam Pengadaan Barang dan Jsa Oleh Pemerintah," Desertasi Program Doktor IImu Hukum Pasca Sarjana Universitas Airlangga, Surabaya

Subekti \& Tjitrosudibyo., 1999. Kitab Undang-Undang hukum Perdata. edisi Revisi. Jakarta: Pradya Paramita. 